\title{
A Brief Review in Effect Factors on Peatland Ecosystem
}

\author{
Ihab Alfadhel \\ School of Environmental Studies, China University of Geosciences, Wuhan, China \\ Email: ihabalfadhel@gmail.com
}

How to cite this paper: Alfadhel, I. (2020) A Brief Review in Effect Factors on Peatland Ecosystem. Open Access Library Journal, 7: e6820.

https://doi.org/10.4236/oalib.1106820

Received: September 14, 2020

Accepted: October 24, 2020

Published: October 27, 2020

Copyright (C) 2020 by author(s) and Open Access Library Inc.

This work is licensed under the Creative Commons Attribution International License (CC BY 4.0).

http://creativecommons.org/licenses/by/4.0/

\begin{abstract}
Peatland ecosystem plays an important role in the global climate change because they act as a pool or sink of the gasses. There are several factors which influence the environmental consequences of peatland especially in relation to climate change. The main influences are: 1) carbon dioxide, 2) methane flux, 3) nitrous oxide $\left(\mathrm{N}_{2} \mathrm{O}\right)$ and 4$)$ others environmental factors. These atmospheric gases concentrates constitute roughly 73 percent of the overall positive energy flux variation. Carbon dioxide is the greenhouse gas considered most consequential in Anthropocene climate change. Methane is a potent greenhouse gas with a global warming potential 34 times greater than carbon dioxide in natural wetlands and the majority of these emissions are from peatlands. Nitrous oxide is one of the main pollutants in the ecosystem of peatlands and can cause eutrophication. This paper is a brief review on environmental factors influences to climate change in peatland ecosystems. It highlights the need for minimizing the negative effects of climate change on wetland ecosystem through proper management of peatlands.
\end{abstract}

\section{Subject Areas}

Environmental Sciences

\section{Keywords}

Peatland, Carbon Dioxide, Methane Flux, Evapotranspiration, Climate Change

\section{Introduction}

Wetland ecosystems cover roughly $6 \%-9 \%$ of the earth's terrestrial surface. They are present in multiple regions across the globe, but are most abundant in the boreal and subarctic regions, where temperatures are cooler and precipita- 
tion amounts are favorable [1]. Wetlands have many characteristics which are notable in the presence of standing water, uniquely soil conditions and species, especially vegetation, that are adapted to and tolerant of saturated soils during the growing season. Hydrological conditions and the role of wetlands as ecotones between land and water systems are unique [2]. In nearly every part of the world, wetlands are located and while many cultures have lived among wetlands for several centuries, and even depended on them, modern wetland history until the 1970s was full of misunderstanding and fear. During the developing world, wetlands were destroyed at alarming rates. The preservation of wetlands in many parts of the world has thus become normal. They are sometimes referred to as landscape kidneys and "supermarkets" for the ecological services and habitat values they provide [2]. Peatlands are wetlands where development levels go above breakdown levels and protected beneath the living plants [3]. The widely accepted definition of a peatland is, "a wetland on which extensive organic material has accumulated" [4]. Peat is a plant material partially decomposed. The most common of the peatlands are in the boreal regions, but also in temperate, tropical and mountainous regions [5] [6] [7]. Peatlands minimum peat mass of $40 \mathrm{~cm}$ is required in the United States for classification as a grass, which categorizes it as Histosol. Peatlands with a minimum thickness of $30 \mathrm{~cm}$ have been identified internationally [8]. Peatlands Have bogs and fens spread mostly in cold boreal areas throughout the world with ample over moisture. Bogs and fens can be formed in several ways, originating either from aquatic systems, as in flow through succession or quaking bogs, or from terrestrial systems, as with blanket bogs. Although many types of peatlands are identifiable, classification according to chemical conditions usually defines three types: 1) minerotrophic (true fens), 2) ombrotrophic (raised bogs), and 3) transition (poor fens). Features of many peatlands include acidity caused by cation exchange with mosses, oxidation of sulfur compounds, and organic acids, low nutrients and primary productivity, slow decomposition, adaptive nutrient-cycling pathways, and peat accumulation. Peatlands collectively are the largest terrestrial storage of carbon on the planet and are seen as potential sources of carbon to the atmosphere if they are disturbed hydrologically or if climate shifts. Many of these lake basins were formed by the last glaciation, and the peatlands are considered to be a late stage of a filling-in process. The various characteristics of peatlands have been examined in multiple [9] [10]. However, most of the literature tends to be focused on peatland ecosystem function, especially their ability to sequester a large amount of Carbon in the soil [11]. Dead plant material in undisturbed peatlands does not decompose as rapidly as it accumulates as peat; making natural peatlands long term sinks of carbon. Moreover, on shorter time scales, natural peatlands are source or sink of carbon depending on the weather conditions of a given year [12] [13]. The carbon and water budgets of peatlands are intricately linked [14]. Disturbances that impact water storage and flows such as climate change or anthropogenic activities (e.g. peat extraction) lead to changes in peatland carbon cycle processes. The two dominant greenhouse gases exchanged 
with the atmosphere from the surface of peatlands are carbon dioxide $\mathrm{CO}_{2}$ and methane $\mathrm{CH}_{4}$, both of which contribute significantly to global warming [15]. Around two thirds of photosynthesis carbon dioxide are produced in cellular respiration [16]. Approximately one third of the carbon is used in cell maintenance and biomass processing. The bio-masses that have been produced contain starch, organic foods, amino acids, polysaccharides, enzymes, lipids and celluloses. When your plant falls or dies biomass, labial carbon compounds can be quickly split up by microbes. Decomposed carbon compounds leave the system in the form of $\mathrm{CO}_{2}, \mathrm{CH}_{4}$ or DOC. Recalcitrant carbon compounds such as lignin are harder to decompose and will last a long time in the system. The decomposition rates of the microbial community are highly affected. Under the growing greenery, high water levels provide an anoxic environment. This anoxic zone helps the formation of peat through oxygen reduction during microbial degradation, as an electron acceptor. Bacteria have been found to exploit rich minerals while fungi have occupied ombrotrophic sites [17]. Microbial communities have a stronger tolerance of acidic conditions [18]. Some bacteria can degrade lignin, but its effectiveness is limited. Related, peatlands are thus defined not necessarily by their climate or anyone floristic species, but by the physical and chemical properties that allow the long-term accumulation of incompletely decomposed plant material. Also, the high-water table effect to lowers soil organic carbon decomposition rates by anoxic conditions and the peatland further grows in depth [19]. Here, this review paper illustrated the effects of environmental factors and climate change on peatlands ecosystem, focusing on the effects of variation in carbon dioxide, methane flux, nitrous oxide and changes the environmental factors in atmosphere composition on peatlands ecosystem. It highlights the need for minimizing the negative effects of climate change on wetland ecosystem through proper management of peatlands.

\section{Effect of Environmental Factors on the Peatland Ecosystem}

The Intergovernmental Panel on Climate Change (IPCC), has continuously analyzed and synthesized thousands of scientific data lines and advanced simulations at different scales, as well as several research teams worldwide, to assert that not only are compelling signs of accelerated climate change, but also that strong evidence of anthropogenic behaviors are responsible for altering global temperature patterns. The IPCC (2013) [20] report indicates that global temperature rise is predicted by $0.3^{\circ} \mathrm{C}$ to $4.8^{\circ} \mathrm{C}$, over $1986-2005$ by the end of the century. The ever-increasing additions of gases to the atmosphere from burning of fossil fuels, where atmospheric gases concentrations have increased from $40 \%$ above pre-industrial levels, tend to accelerate these patterns [20]. Such atmospheric gases concentrates constitute roughly 73 percent of the overall positive energy flux variation [21] [22], estimated by the latest global climate change of $0.85^{\circ} \mathrm{C}$ from 1880 to 2012 [20]. The cumulative impacts (temperature, atmospheric gases and precipitation) of these climate change influences are likely to 
alter peat environments around the world, disrupting many critical ecological mechanisms and functions [23]. As a result, several research goals for assessing the individual and interactive impact of these climate change influences on specific peatland ecosystem processes [24]. For example, by 2100 high latitude regions are predicted to be up to $11^{\circ} \mathrm{C}$ warmer than recent averages, about $7^{\circ} \mathrm{C}$ warmer than the projected global average warming [20]. Accordingly, an important research goal of winter peatlands is to consider the effect of climate change on structure and operation of the peatlands habitats in high-latitude environments [25]. In future climactic conditions, these increased climatic conditions are expected to cause many high latitude habitats to become warmer and drier in an unprecedented way than many other habitats across the globe, particularly in combination.

\section{Effect of Carbon Dioxide $\left(\mathrm{CO}_{2}\right)$}

Carbon dioxide is the greenhouse gas considered most consequential in Anthropocene climate change [26]. Plants, cyanobacteria, and algae capture and derive energy from atmospheric $\mathrm{CO}_{2}$ through photosynthesis; all aerobic organisms produce $\mathrm{CO}_{2}$ through respiration. $\mathrm{CO}_{2}$ emissions from peatlands as well as that produced through decomposition [27] [28]. The physiological differences in peatlands must be considered. Temperature, water table and availability of organic substrates have been shown to be controlling factors of $\mathrm{CO}_{2}$ emissions from peatlands [29] [30]. The effect of water table height on $\mathrm{CO}_{2}$ has been shown in a number of peatland studies. Freeman et al. (1993) [31] found that $\mathrm{CO}_{2}$ emissions increased during a simulated drought in Welsh peatland of wales. Funk et al. (1994) [32] also found that $\mathrm{CO}_{2}$ emissions tripled when the water table was lowered below the peat surface in microcosm cores of a bog near Fairbanks, Alaska in March 1991. Chimner and Cooper (2003) [30] observed that $\mathrm{CO}_{2}$ fluxes were highest when temperature was high within the lowest water table in Colorado subalpine fen in early June 1998. They attributed this to increases in mineralization of plant material in the aerobic environment. No high correlations were found between $\mathrm{CO}_{2}$ fluxes and any variable measured (depth, age, $\mathrm{pH}$, water temperature, wind speed, transparency, etc.) in a number of lakes, rivers in peatlands of Candia [33]. $\mathrm{CO}_{2}$ flux has consistently increased in atmospheric during the modern era [34], and is critical to Earth's present and future climatic conditions. Related, a previous research demonstrates the variations of $\mathrm{CO}_{2}$ emissions from peatlands such as Draper et al. (2014) [35] has shown in 2014 the variation of carbon dioxide in Amazonian peatlands forests, USA was $3.14 \mathrm{~g} \cdot \mathrm{C} \cdot \mathrm{m}^{-2} \cdot \mathrm{yr}^{-1}$ (Table 1). Lloyd (2006) [36] in meadow peatland of Tadham, UK between 2000 to 2003 has shown the variation was $59 \mathrm{~g} \cdot \mathrm{C} \cdot \mathrm{m}^{-2} \cdot \mathrm{yr}^{-1}$ (Table 1). Syed et al. (2006) [37] in Boreal fen of Alberta, Canada shows the variation of carbon dioxide between (2002-2003) is $-144 \mathrm{~g} \cdot \mathrm{C} \cdot \mathrm{m}^{-2} \cdot \mathrm{yr}^{-1}$ (Table 1). A number of novel methods, notably the cuvette method, were developed to measure $\mathrm{CO}_{2}$ exchange in both laboratory settings and in situ prior to modern micrometeorological technology [38]. Based on Table 1, the emergence of an appreciable body of literature on carbon exchange in fen peatlands using eddy 
Table 1. Carbon dioxide observations from peatlands ecosystems around the world.

\begin{tabular}{|c|c|c|c|c|c|}
\hline Year & Country & Site & Type & $\begin{array}{c}\text { Value } \\
\mathrm{g} \cdot \mathrm{C} \cdot \mathrm{m}^{-2} \cdot \mathrm{yr}^{-1}\end{array}$ & Source \\
\hline 2014 & Amazonian peatlands, USA & & peatland forests & 3.14 & Draper et al. (2014) [35] \\
\hline 2002 & Tadham.UK & $\begin{array}{c}5181202600 \mathrm{~N} \\
2849^{\prime} 4300 \mathrm{~W}\end{array}$ & meadow & 59 & Lloyd (2006) [36] \\
\hline 2003-2004 & Alberta, Canada & $54.95^{\circ} \mathrm{N},-112.47^{\circ} \mathrm{E}$ & Boreal fen & -144 & Syed et al. (2006) [37] \\
\hline 2014-2016 & Newfoundland, Canada & $48.26^{\circ} \mathrm{N},-58.67^{\circ} \mathrm{E}$ & Boreal bog & $-46 \pm 35$ & Wang et al. (2018) [46] \\
\hline 2004-2005 & Pirkanmaa, Finland & $61.83^{\circ} \mathrm{N}, 24.19^{\circ} \mathrm{E}$ & Boreal fen & -111 & Aurela et al. (2007) [41] \\
\hline $1997-2002$ & Lapland, Finland & $69.13^{\circ} \mathrm{N}, 27.28^{\circ} \mathrm{E}$ & Subarctic fen & $-21.5 \pm 19.8$ & Aurela et al. (2004) [47] \\
\hline 2012-2013 & Bavaria, Germany & $47.80^{\circ} \mathrm{N}, 11.32^{\circ} \mathrm{E}$ & Temperate bog pine & -62 & Hommeltenberg et al. (2014) [48] \\
\hline 2002-2012 & Kerry, Ireland & $51.92^{\circ} \mathrm{N}, 9.92^{\circ} \mathrm{E}$ & Atlantic blanket Bog & $-55.7 \pm 18.9$ & McVeigh et al. (2014) [49] \\
\hline 4.5-year record & Norwegian, Norway & $69.13^{\circ} \mathrm{N}, 16.01^{\circ} \mathrm{E}$ & Boreal blanket bog & $-19.5 \pm 18.3$ & Lund et al. (2015) [50] \\
\hline 2005-2006 & Skåne, Sweden & $56.25^{\circ} \mathrm{N}, 13.55^{\circ} \mathrm{E}$ & Temperate bog & $-21 \pm 5.4$ & Lund et al. (2009) [51] \\
\hline 2009-2011 & Minnesota, USA & $47.51^{\circ} \mathrm{N},-93.49^{\circ} \mathrm{E}$ & Temperate poor fen & -19 & Olson et al. (2013) [52] \\
\hline 2006-2007 & Ontario, Canada & $45.41^{\circ} \mathrm{N},-75.48^{\circ} \mathrm{E}$ & Cool-temperate bog & $-40.2,-104$ & Strilesky and Humphreys (2012) [53] \\
\hline
\end{tabular}

covariance techniques in Lapland, Finland in 1997s and 2002s was found -21.5 $\pm 19.8 \mathrm{~g} \cdot \mathrm{C} \cdot \mathrm{m}^{-2} \cdot \mathrm{yr}^{-1}$. Related, researchers have elicited several important factors or drivers of peatland $\mathrm{CO}_{2}$ exchange, including but not limited to plant community structure and composition [38] [39]; weather conditions [40] [41]; volumetric soil moisture [42] [43]; and water table position [44] [45]. Table 1 illustrated the carbon dioxide has an effect on different kinds of peatland.

\section{Effect of Methane Flux $\left(\mathrm{CH}_{4}\right)$}

Methane is a potent greenhouse gas with a global warming potential 34 times greater than carbon dioxide in natural wetlands [54] [55] [56]. The majority of these emissions are from tropical wetlands and peatlands [57]. Anaerobic conditions of peatlands as well as accumulation of large amounts of organic matter provide a favorable environment for $\mathrm{CH}_{4}$ production [58]. Methane production is inhibited by sulfate as sulfate-reducing bacteria out-compete methanogenic bacteria for organic substrates [59]. Global $\mathrm{CH}_{4}$ cycling is driven naturally by microbial activity underneath the earth's soil surface of the peatland area [60]. If the soil of a wetland is not completely inundated, $\mathrm{CH}_{4}$ will be consumed via oxidation by methanotrophic bacteria in the aerobic layer (vadose zone) of the soil. Methanogenic Archaea convert fermented organic matter into $\mathrm{CH}_{4}$ through the acetate pathway (acetogenic microorganisms) or the hydrogen pathway (hydrogenic microorganisms); though acetogenesis is more common worldwide and in fens, hydrogenesis tends to dominate in ombrotrophic bogs lacking acetate from 
vascular vegetation [60] [61]. Once produced by these anaerobes, $\mathrm{CH}_{4}$ gas can reach the atmosphere by three processes: direct diffusion through the soil, episodic ebullition events releasing "bubbles" of $\mathrm{CH}_{4}$ gas; and root transport through the aerenchyma vessels of plants such as Typha [55] [62] [63]. Dominant determinants of $\mathrm{CH}_{4}$ emissions from peatlands are water table position, soil temperature, quality and availability of substrate, and mode of gas transport to the atmosphere [64]. Freeman et al. (1993) [31] observed decreased $\mathrm{CH}_{4}$ flux in peat microcosms during a simulated drought but poor correlations were found between $\mathrm{CH}_{4}$ flux and water table height. Methanogenesis is the process by which certain Archaea produce $\mathrm{CH}_{4}$ in anaerobic environments, such as in flooded wetlands below the water table. A meta-review of 87 peatland studies by Abdalla et al. (2016) [65] found the primary controls of peatland $\mathrm{CH}_{4}$ flux to be soil $\mathrm{pH}$, vegetation composition, and water table depth. Methane also has secondary impacts on ambient aerosols, ozone and other compounds [66]. Table 2 demonstrates positive correlations between $\mathrm{CH}_{4}$ flux and different kinds of peatlands ecosystem, in 1998-2004, the concentration of atmospheric $\mathrm{CH}_{4}$ is 0.06 - $0.08 \mu \mathrm{mol} \cdot \mathrm{m}^{-2} \cdot \mathrm{s}^{-1}$ in bog peatland of Canada. In 2005, the concentrations of $\mathrm{CH}_{4}$ are $0.02-0.06 \mu \mathrm{mol} \cdot \mathrm{m}^{-2} \cdot \mathrm{s}^{-1}$ in Blanket peat of England [67] fluxes in a northern peatland. The various natural $\mathrm{CH}_{4}$ sinks and sources may significantly contribute to global change in $\mathrm{CH}_{4}$ abundance. From 2011-2014, the variation of methane flux in Minnesota peatland of USA is $0.3-0.5 \mu \mathrm{mol} \cdot \mathrm{m}^{-2} \cdot \mathrm{s}^{-1}[68]$.

Table 2. Methane flux observations from peatlands ecosystems around the world.

\begin{tabular}{|c|c|c|c|c|c|}
\hline Year & Country & Site & Type & $\begin{array}{c}\text { Value } \\
\mu \mathrm{mol} \cdot \mathrm{m}^{-2} \cdot \mathrm{s}^{-1}\end{array}$ & Source \\
\hline $2006-2007$ & Scotland & $55^{\circ} 480 \mathrm{~N}, 3^{\circ} 14035 \mathrm{~W}$ & Peatlands & $0.10 \pm 0.02$ & Dinsmore et al. (2009) [69] \\
\hline 1995 & Scotland & $55^{\circ} 050 \mathrm{~N}$ & Bog & 0.01 & Clymo et al. (1995) [70] \\
\hline $2003-2005$ & Ireland & $51^{\circ} 550 \mathrm{~N}$ & Bog & 0.2 & Laine et al. (2007) [71] \\
\hline $2003-2008$ & Ireland & $51^{\circ} 550 \mathrm{~N}$ & Bog & 0.01 & Koehler et al. (2011) [72] \\
\hline 2011-2014 & USA & $\mathrm{N} 47^{\circ} 30.4760 ; \mathrm{W} 93^{\circ} 27.162$ & Minnesota peatland & $0.3-0.5$ & Hanson et al. (2016) [68] \\
\hline $2009-2011$ & USA & $47.505 \mathrm{~N},-93.489 \mathrm{~W}$ & Fen & $0.22-0.29$ & Olson et al. (2013) [52] \\
\hline $2008-2011$ & USA & $46^{\circ} 190 \mathrm{~N}, 86^{\circ} 030 \mathrm{~W}$ & Fen & $0.002-0.011$ & Ballantyne et al. (2014) [73] \\
\hline $2002-2003$ & Canada & $45^{\circ} 250 \mathrm{~N}, 75.48^{\circ} \mathrm{W}$ & Bog & 0.7 & Moore et al. (2011) [74] \\
\hline $2009-2010$ & Canada & $45.41^{\circ} \mathrm{N}, 75.52^{\circ} \mathrm{W}$ & Bog & 0.6 & Lai et al. (2014) [75] \\
\hline $1998-2004$ & Canada & $45.411 \mathrm{~N}, 75.481 \mathrm{~W}$ & Bog & $0.06-0.08$ & Roulet et al. (2007) [12] \\
\hline $2003-2004$ & Canada & $45^{\circ} 410 \mathrm{~N}$ & Bog & $0.01-0.03$ & (Blodau et al. 2007) [76] \\
\hline 1998 & Canada & $45^{\circ} 330 \mathrm{~N}, 66.49 \mathrm{~W}$ & fen and bog & 0.17 & Moore and Knowles (1990) [77] \\
\hline 2005 & England & $54^{\circ} 650 \mathrm{~N}, 2^{\circ} 45^{\prime} \mathrm{W}$ & Blanket peat & $0.02-0.06$ & McNamara et al. (2008) [67] \\
\hline
\end{tabular}




\section{Effect of Evapotranspiration (ET)}

High biodiversity and hydrological functions including flood control, low flux support, nutrient cycling, and ground water recharge have become increasingly recognized in wetlands. Hydrology of peatlands is a key driving force for the environment, its development and its continued existence for water quality assessment, the exact calculation of water loss from ET is quite relevant [78], making proper water resources plans [79]. However, Different types of peatlands are difficult, expensive and seldom available to direct ET measurement. A number of studies have been carried out on peatlands evapotranspiration, due to the different conditions of peatland and the methods used, the results have differed greatly [79] [80] [81]. Researchers explored the available methods for quantifying evapotranspiration and concluded that covariance of eddies is an especially promising instrument. Recent advances in the reliability of eddy covariance devices have allowed long-term eddy covariance data to be collected above several types of vegetation [82] [83], including wetlands [84] [85].

ET is released from molecular diffusion, boiling and plant transportation to the atmosphere [86]. Many factors affect ET flux mechanisms, including water conditions [87] [88], and latent heat flux (LE), the largest consumer of incoming energy [89] [90]. With increasing temperatures and precipitation, peatlands have undergone significant climate change. Environmental factors that increase ET in the atmosphere affect the composition and productivity of plant species [91]. Figure 1 illustrated the daily variation of ET was 0.028 from January till end of march 2018 in Dajiuhu peatland in central china and agree with a previous study in a bog peatland in southern Ontario of Canada, and the results indicate a number of characteristics of the association of ET ratio for all days was 0.517 $\mathrm{mm} / \mathrm{hr}$, this results suggesting there was strong surface control on daily ET at this site [88]. Cao et al. (2020) [92] illustrated, the daily ET in growing periods varied from 0.28 to $4.73 \mathrm{~mm} / \mathrm{hr}$ in the Qinghai Lake basin, of northwest China. ET has flux to the atmospheric due to a variation of environmental variables and peat respiration.

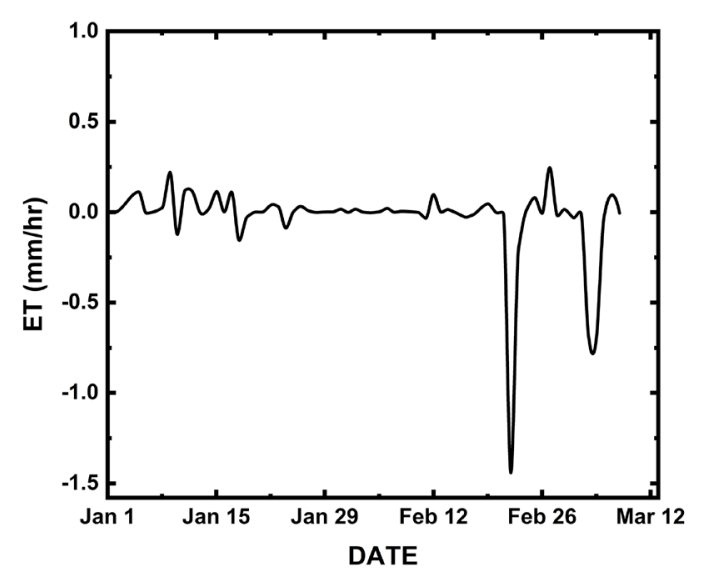

Figure 1. Daily variation of evapotranspiration from January until March of 2018 in peatland of Central China. 


\section{Effect of Nitrous Oxide $\left(\mathrm{N}_{2} \mathrm{O}\right)$}

Nitrous oxide is one of the main pollutants in the ecosystem of peatlands and can cause eutrophication, affect water-borne oxygen levels and increase the aquatic species toxicity. Nitrous oxide exists in wetlands ecosystem an inorganic forms and recognized the inadequacy in the number. Groffman et al. (1998) [93] studies relating high denitrification rates and $\mathrm{N}_{2} \mathrm{O}$ emissions in riparian areas and further suggests that $\mathrm{N}_{2} \mathrm{O}$ emissions may be low due to the highly anaerobic conditions found in many riparian zone soils. Table 3 demonstrated increased in nitrous oxide emissions in permafrost of Finland in 2012 and the values are $2.81 \pm 0.6 \mathrm{mg} \cdot \mathrm{m}^{-2} \cdot \mathrm{d}^{-1}$ [94]. In a review by Saunders and Kalff (2001) [95] denitrification accounted for $63 \%$ of total $\mathrm{N}_{2} \mathrm{O}$ removal in lakes. Combined studies of denitrification and $\mathrm{N}_{2} \mathrm{O}$ emissions are lacking and the contribution of $\mathrm{N}_{2} \mathrm{O}$ emissions from prairie wetlands is not well defined but is expected to be low as the water-saturated environment would promote the formation of $\mathrm{N}_{2}$ rather than $\mathrm{N}_{2} \mathrm{O}$ as $\mathrm{N}_{2}$ is the dominant gas produced when the waterfilled pore space exceeds $80 \%$ [96].

The few existing $\mathrm{N}_{2} \mathrm{O}$ estimates from water bodies come from an extensive study by Tremblay et al. (2005) [33] in which 125 water bodies were sampled for greenhouse gases $\mathrm{N}_{2} \mathrm{O}$ and other nitrogen oxides are formed during nitrification and denitrification processes at suboptimal conditions [97]. Martikainen et al. (1993) [98] demonstrate $\mathrm{N}_{2} \mathrm{O}$ emission may be affected by various operating parameters and environmental conditions such as Dissolved oxidation, oxidation-reduction potential and water temperature, among other factors in 1992 of Finland peatland. The formation of nitrogen oxides can be avoided by high $\mathrm{BOD} / \mathrm{N}$ ratio and low $\mathrm{O}_{2} / \mathrm{NOx}$ ratios for denitrification, long denitrification residence time, and avoiding simultaneous $\mathrm{NH}_{4}$ oxidation and $\mathrm{NO}_{2}$-reduction [97]. Arai et al. (2014) [99] explained the change affects microbial biomass and fluxes of carbon dioxide and nitrous oxide in tropical peatlands of Indonesia and the value is $26.06 \mathrm{mg} \cdot \mathrm{m}^{-2} \cdot \mathrm{d}^{-1}$ between $2009-2011$ (Table 3). A previous research by

Table 3. Nitrous Oxide observations from peatlands ecosystems around the world.

\begin{tabular}{|c|c|c|c|c|c|}
\hline Year & Country & Site & Type & $\begin{array}{c}\text { Value } \\
\mathrm{mg} \cdot \mathrm{m}^{-2} \cdot \mathrm{d}^{-1}\end{array}$ & Source \\
\hline 1992 & Finland & $62.51 \mathrm{~N}, 30.53 \mathrm{E}$ & peatland & $2.5-8.6$ & Martikainen et al. (1993) [98] \\
\hline $1977-2006$ & Russian & $671030 \mathrm{~N}, 621570 \mathrm{E}$ & permafrost peatlands & $0.9-0.1$ & Marushchak et al. (2011) [101] \\
\hline 1998-1999 & Malaysia & & Tropical peatlands & 1.04 & Hadi et al. (2000) [102] \\
\hline $1961-1990$ & Finland & $\begin{array}{c}60^{\circ} 21^{\circ} \mathrm{N}, 25^{\circ} 03^{\circ} \mathrm{E},-61^{\circ} 23^{\circ} \mathrm{N} \\
25^{\circ} 03^{\circ} \mathrm{E}, 125\end{array}$ & forest peatlands & $0.945-0.246$ & Huttunen et al. (2003) [103] \\
\hline 1991-1996 & Finland & $61^{\circ} 48^{\circ} \mathrm{N}, 24^{\circ} 19^{\circ} \mathrm{E}$ & boreal peatland & 1.7 & Nykänen et al. (2002) [104] \\
\hline 2012 & Finland & $68^{\circ} 89^{\prime} \mathrm{N}, 21^{\circ} 05^{\prime} \mathrm{E}$ & permafrost & $2.81 \pm 0.6$ & Voigt et al. (2017) [94] \\
\hline 2009-2011 & Indonesia & $\begin{array}{c}2^{\circ} 17^{\prime}-2^{\circ} 21^{\prime} \mathrm{S} \\
113^{\circ} 54^{\prime}-114^{\circ} 01^{\prime} \mathrm{E}\end{array}$ & tropical peatlands & 26.06 & Arai et al. (2014) [99] \\
\hline
\end{tabular}


Khirul et al. (2020) [100] approved that the total nitrogen and slightly increased nitrate/nitrite, probably due to the facilitation of microbial degrading activity in the southeast coast of South Korea.

\section{Conclusion}

This paper is brief review to illustrate the effects of environmental factors and climate change on wetlands ecosystem. Principal processes leading to the production and sinking of carbon dioxide, methane flux and Nitrous oxide in peatland ecosystem of china are presented and discussed mainly. The cumulative impacts atmospheric gases of these climate change influences are likely to alter peat environments around the world, disrupting many critical ecological mechanisms and functions. It is apparent that there is need for continued short and long-term research to better understand peatlands ecosystem and how they affect our climate. This will hopefully provide the basis for predicting better what could happen under various scenarios.

\section{Acknowledgements}

Many thanks go to lab mates and others for helping to collect relevant data.

\section{Conflicts of Interest}

The author declares no conflicts of interest regarding the publication of this paper.

\section{References}

[1] Batzer, D.P. and Baldwin, A.H. (2012) Wetland Habitats of North America. University of California Press, Berkeley, 119-134. https://doi.org/10.1525/9780520951419

[2] Mitsch, G. (2016) Wetlands (5th Edition). Wiley, Hoboken.

[3] Clymo, R.S. (1984) The Limits to Peat Bog Growth. Philosophical Transactions of the Royal Society of London. Series B, Biological Sciences, 303, 605-654.

[4] Rankin, T. (2016) An Analysis of Carbon Dioxide and Methane Exchange at a Post-Extraction, Unrestored Peatland in Eastern Québec.

[5] Jaenicke, J., Rieley, J.O., Mott, C., Kimman, P. and Siegert, F. (2008) Determination of the Amount of Carbon Stored in Indonesian Peatlands. Geoderma, 147, 151-158. https://doi.org/10.1016/j.geoderma.2008.08.008

[6] Lähteenoja, O., Ruokolainen, K., Schulman, L. and Alvarez, J. (2009) Amazonian Floodplains Harbour Minerotrophic and Ombrotrophic Peatlands. Catena, 79, 140-145. https://doi.org/10.1016/j.catena.2009.06.006

[7] Tiner, R. (2017) Wetland Indicators. CRC Press, Boca Raton. https://doi.org/10.1201/9781315374710

[8] Rydin, H. and Jeglum, J.K. (2013) The Biology of Peatlands. 2nd Edition, Oxford University Press, Oxford. https://doi.org/10.1093/acprof:osobl/9780199602995.001.0001

[9] Kennedy, G. and Mayer, T. (2002) Natural and Constructed Wetlands in Canada: An Overview. Water Quality Research Journal of Canada, 37, 295-325. https://doi.org/10.2166/wqri.2002.020 
[10] Andersen, R., Rochefort, L. and Poulin, M. (2010) Peat, Water and Plant Tissue Chemistry Monitoring: A Seven-Year Case-Study in a Restored Peatland. Wetlands, 30, 159-170. https://doi.org/10.1007/s13157-009-0015-0

[11] Lafleur, P.M. (2009) Connecting Atmosphere and Wetland: Trace Gas Exchange. Geography Compass, 3, 560-585. https://doi.org/10.1111/j.1749-8198.2008.00212.x

[12] Roulet, N.T., Lafleur, P.M., Richard, P.J.H., Moore, T.R., Humphreys, E.R. and Bubier, J. (2007) Contemporary Carbon Balance and Late Holocene Carbon Accumulation in a Northern Peatland. Global Change Biology, 13, 397-411. https://doi.org/10.1111/j.1365-2486.2006.01292.x

[13] Rieley, J., Jauhiainen, J. and Page, S. (2008) Peatlands and Climate Change.

[14] Waddington, J.M., Morris, P.J., Kettridge, N., Granath, G., Thompson, D.K. and Moore, P.A. (2015) Hydrological Feedbacks in Northern Peatlands. Ecohydrology, 8, 113-127. https://doi.org/10.1002/eco.1493

[15] Kayranli, B., Scholz, M., Mustafa, A. and Hedmark, Å. (2010) Carbon Storage and Fluxes within Freshwater Wetlands: A Critical Review. Wetlands, 30, 111-124. https://doi.org/10.1007/s13157-009-0003-4

[16] Litton, C.M., Raich, J.W. and Ryan, M.G. (2007) Carbon Allocation in Forest Ecosystems. Global Change Biology, 13, 2089-2109. https://doi.org/10.1111/j.1365-2486.2007.01420.x

[17] Golovchenko, A.V., Tikhonova, E.I. and Zviagintsev, D.G. (2007) Abundance, Biomass, Structure, and Activity of the Microbial Complexes of Minerotrophic and Ombrotrophic Peatlands. Mikrobiologiia, 76, 711-719. https://doi.org/10.1134/S0026261707050177

[18] Winsborough, C. and Basiliko, N. (2010) Fungal and Bacterial Activity in Northern Peatlands. Geomicrobiology Journal, 27, 315-320. https://doi.org/10.1080/01490450903424432

[19] Wieder, R.K., Vitt, D.H. and Benscoter, B.W. (2006) Peatlands and the Boreal Forest. In: Boreal Peatland Ecosystems, Springer, Berlin, 1-8. https://doi.org/10.1007/978-3-540-31913-9_1

[20] IPCC (2013) Climate Change 2013-The Physical Science Basis: Summary for Policymakers, Technical Summary and Frequently Asked Questions.

[21] Allen, M.R., Frame, D.J., Huntingford, C., Jones, C.D., Lowe, J.A., Meinshausen, et al. (2009) Warming Caused by Cumulative Carbon Emissions towards the Trillionth Tonne. Nature, 458, 1163-1166. https://doi.org/10.1038/nature08019

[22] Gillett, N.P., Arora, V.K., Matthews, D. and Allen, M.R. (2013) Constraining the Ratio of Global Warming to Cumulative $\mathrm{CO}_{2}$ Emissions Using CMIP5 Simulations. Journal of Climate, 26, 6844-6858. https://doi.org/10.1175/JCLI-D-12-00476.1

[23] Grimm, N.B., Chapin, F.S., Bierwagen, B., Gonzalez, P., Groffman, P.M., Luo, Y., Melton, F., et al. (2013) The Impacts of Climate Change on Ecosystem Structure and Function. Frontiers in Ecology and the Environment, 11, 474-482. https://doi.org/10.1890/120282

[24] Xia, J., Liang, S., Chen, J., Yuan, W., Liu, S., Li, L., et al. (2014) Satellite-Based Analysis of Evapotranspiration and Water Balance in the Grassland Ecosystems of Dryland East Asia. PLoS ONE, 9, e97295. https://doi.org/10.1371/journal.pone.0097295

[25] Bu, Z., Hans, J., Li, H., Zhao, G., Zheng, X., Ma, J. and Zeng, J. (2011) The Response of Peatlands to Climate Warming: A Review. Acta Ecologica Sinica, 31, 157-162. https://doi.org/10.1016/j.chnaes.2011.03.006 
[26] Bridgham, S.D., Cadillo-Quiroz, H., Keller, J.K. and Zhuang, Q. (2013) Methane Emissions from Wetlands: Biogeochemical, Microbial, and Modeling Perspectives from Local to Global Scales. Global Change Biology, 19, 1325-1346. https://doi.org/10.1111/gcb.12131

[27] Blais, A.-M., Lorrain, S. and Tremblay, A. (2005) Greenhouse Gas Fluxes $\left(\mathrm{CO}_{2}, \mathrm{CH}_{4}\right.$ and $\mathrm{N}_{2} \mathrm{O}$ ) in Forests and Wetlands of Boreal, Temperate and Tropical Regions. In: Greenhouse Gas Emissions-Fluxes and Processes, Springer, Berlin, 87-127. https://doi.org/10.1007/978-3-540-26643-3_5

[28] Alfadhel, I., Ge, J. and Issaka, S. (2020) Net Ecosystem $\mathrm{CO}_{2}$ Flux and Effect Factors in Peatland Ecosystem of Central China. Geosciences and Environment Protection, 8, 95-106. https://doi.org/10.4236/gep.2020.88008

[29] Bridgham, S.D., Johnston, C.A., Pastor, J. and Updegraff, K. (1995) Potential Feedbacks of Northern Wetlands on Climate Change-An Outline of an Approach to Predict Climate-Change Impact. Bioscience, 45, 262-274.

https://doi.org/10.2307/1312419

[30] Chimner, R.A. and Cooper, D.J. (2003) Influence of Water Table Levels on $\mathrm{CO}_{2}$ Emissions in a Colorado Subalpine Fen: An in Situ Microcosm Study. Soil Biology and Biochemistry, 35, 345-351. https://doi.org/10.1016/S0038-0717(02)00284-5

[31] Freeman, C., Lock, M. and Reynolds, B. (1993) Fluxes of $\mathrm{CO}_{2}, \mathrm{CH}_{4}$, and $\mathrm{N}_{2} \mathrm{O}$ from a Welsh Peatland Following Simulation of Water Table Draw-Down: Potential Feedback for Climate Change. Bigeochemistry, 19, 51-60. https://doi.org/10.1007/BF00000574

[32] Funk, D.W., Pullman, E.R., Peterson, K.M., Crill, P.M. and Billings, W.D. (1994) Influence of Water Table on Carbon Dioxide, Carbon Monoxide, and Methane Fluxes from Taiga Bog Microcosms. Global Biogeochemical Cycles, 8, 271-278. https://doi.org/10.1029/94GB01229

[33] Tremblay, A., Therrien, J., Hamlin, B., Wishmann, E., et al. (2005) GHG Emissions from Boreal Reservoirs and Natural Aquatic Ecosystems. In: Greenhouse Gas Emissions-Fluxes and Processes, Springer, Berlin, 209-232. https://doi.org/10.1007/978-3-540-26643-3_9

[34] Keeling, C.D., Bacastow, R.B. and Bainbridge, A.E. (1976) Atmospheric Carbon Dioxide Variations at Mauna Loa Observatory, Hawaii. Tellus, 28, 538-551. https://doi.org/10.3402/tellusa.v28i6.11322

[35] Draper, F.C., Roucoux, K.H., Lawson, I.T., Mitchard, E.T.A., Honorio Coronado, E.N., Lähteenoja, et al. (2014) The Distribution and Amount of Carbon in the Largest Peatland Complex in Amazonia. Environmental Research Letters, 9, Article ID: 124017. https://doi.org/10.1088/1748-9326/9/12/124017

[36] Lloyd, C.R. (2006) Annual Carbon Balance of a Managed Wetland Meadow in the Somerset Levels, UK. Agricultural and Forest Meteorology, 138, 168-179. https://doi.org/10.1016/j.agrformet.2006.04.005

[37] Syed, K.H., Flanagan, L.B., Carlson, P.J., Glenn, A.J. and Van Gaalen, K.E. (2006) Environmental Control of Net Ecosystem $\mathrm{CO}_{2}$ Exchange in a Treed, Moderately Rich Fen in Northern Alberta. Agricultural and Forest Meteorology, 140, 97-114. https://doi.org/10.1016/j.agrformet.2006.03.022

[38] Mooney, H.A. (1972) Carbon Dioxide Exchange of Plants in Natural Environments. The Botanical Review, 38, 455-469. https://doi.org/10.1007/BF02860011

[39] Glenn, A.J., Flanagan, L.B., Syed, K.H. and Carlson, P.J. (2006) Comparison of Net Ecosystem $\mathrm{CO}_{2}$ Exchange in Two Peatlands in Western Canada with Contrasting Dominant Vegetation, Sphagnum and Carex. Agricultural and Forest Meteorology, 
140, 115-135. https://doi.org/10.1016/j.agrformet.2006.03.020

[40] Lafleur, P.M., Roulet, N.T. and Admiral, S.W. (2001) Annual Cycle of $\mathrm{CO}_{2}$ Exchange at a Bog Peatland. Journal of Geophysical Research: Atmospheres, 106, 3071-3081. https://doi.org/10.1029/2000JD900588

[41] Aurela, M., Riutta, T., Laurila, T., Tuovinen, J.P., Vesala, T., Tuittila, E.S., et al. (2007) $\mathrm{CO}_{2}$ Exchange of a Sedge fen in Southern Finland-The Impact of a Drought Period. Tellus. Series B: Chemical and Physical Meteorology, 59, 826-837. https://doi.org/10.1111/j.1600-0889.2007.00309.x

[42] Griffis, T.J., Rouse, W.R. and Waddington, J.M. (2000) Interannual Variability of Net Ecosystem $\mathrm{CO}_{2}$ Exchange at a Subarctic Fen. Global Biogeochemical Cycles, 14, 1109-1121. https://doi.org/10.1029/1999GB001243

[43] McNeil, P. and Waddington, J.M. (2003) Moisture Controls on Sphagnum Growth and $\mathrm{CO}_{2}$ Exchange on a Cutover Bog. Journal of Applied Ecology, 40, 354-367. https://doi.org/10.1046/j.1365-2664.2003.00790.x

[44] Moore, T.R. and Knowles, R. (1989) The Influence of Water Table Levels on Methane and Carbon Dioxide Emissions from Peatland Soils. Canadian Journal of Soil Science, 69, 33-38. https://doi.org/10.4141/cjss89-004

[45] Lafleur, P.M., Roulet, N.T., Bubier, J.L., Frolking, S. and Moore, T.R. (2003) Interannual Variability in the Peatland-Atmosphere Carbon Dioxide Exchange at an Ombrotrophic Bog. Global Biogeochemical Cycles, 17, 5-14. https://doi.org/10.1029/2002GB001983

[46] Wang, M., Wu, J., Lafleur, P.M., Luan, J., Chen, H. and Zhu, X. (2018) Can Abandoned Peatland Pasture Sequestrate More Carbon Dioxide from the Atmosphere than an Adjacent Pristine Bog in Newfoundland, Canada? Agricultural and Forest Meteorology, 248, 91-108. https://doi.org/10.1016/j.agrformet.2017.09.010

[47] Aurela, M., Laurila, T. and Tuovinen, J.P. (2004) The Timing of Snow Melt Controls the Annual $\mathrm{CO}_{2}$ Balance in a Subarctic Fen. Geophysical Research Letters, 31, 16. https://doi.org/10.1029/2004GL020315

[48] Hommeltenberg, J., Mauder, M., Drösler, M., Heidbach, K., Werle, P. and Schmid, H.P. (2014) Ecosystem Scale Methane Fluxes in a Natural Temperate Bog-Pine Forest in Southern Germany. Agricultural and Forest Meteorology, 198, 273-284. https://doi.org/10.1016/j.agrformet.2014.08.017

[49] McVeigh, P., Sottocornola, M., Foley, N., Leahy, P. and Kiely, G. (2014) Meteorological and Functional Response Partitioning to Explain Interannual Variability of $\mathrm{CO}_{2}$ Exchange at an Irish Atlantic Blanket Bog. Agricultural and Forest Meteorolo$g y$, 194, 8-19. https://doi.org/10.1016/j.agrformet.2014.01.017

[50] Lund, M., Bjerke, J.W., Drake, B.G., Engelsen, O., Hansen, G.H., Parmentier, et al. (2015) Low Impact of Dry Conditions on the $\mathrm{CO}_{2}$ Exchange of a Northern-Norwegian Blanket Bog. Environmental Research Letters, 10, Article ID: 025004.

[51] Lund, M., Lindroth, A., Christensen, T.R. and Ström, L. (2009) Annual $\mathrm{CO}_{2}$ Balance of a Temperate Bog. Medd fran Lunds Univ Geogr Institutioner, Avh.

[52] Olson, D.M., Griffis, T.J., Noormets, A., Kolka, R. and Chen, J. (2013) Interannual, Seasonal, and Retrospective Analysis of the Methane and Carbon Dioxide Budgets of a Temperate Peatland. Journal of Geophysical Research: Biogeosciences, 118, 226-238. https://doi.org/10.1002/jgrg.20031

[53] Strilesky, S.L. and Humphreys, E.R. (2012) A Comparison of the Net Ecosystem Exchange of Carbon Dioxide and Evapotranspiration for Treed and Open Portions of a Temperate Peatland. Agricultural and Forest Meteorology, 153, 45-53. 
https://doi.org/10.1016/j.agrformet.2011.06.006

[54] Ciais, P., Sabine, C., Bala, G., Bopp, L., Brovkin, V., Canadell, J., Chhabra, A., et al. (2013) Carbon and Other Biogeochemical Cycles. In: Climate Change 2013: The Physical Science Basis. Contribution of Working Group I to the Fifth Assessment Report of the Intergovernmental Panel on Climate Change, Cambridge University Press, Cambridge, 465-570.

[55] Alfadhel, I., Ge, J., Sinan, Y. and Liu, Y. (2019) Methane Flux and Its Environmental Impact Factors in Dajiuhu Wetland of Shennongjia. Wuhan University Journal of Natural Sciences, 24, 455-460. https://doi.org/10.1007/s11859-019-1421-7

[56] Zhang, M., Xiao, Q., Zhang, Z., Gao, Y., Zhao, J., Pu, Y., et al. (2019) Methane Flux Dynamics in a Submerged Aquatic Vegetation Zone in a Subtropical Lake. Science of the Total Environment, 672, 400-409. https://doi.org/10.1016/j.scitotenv.2019.03.466

[57] Bartlett, K.B. and Harriss, R.C. (1993) Review and Assessment of Methane Emissions from Wetlands. Chemopshere, 26, 261-320.

https://doi.org/10.1016/0045-6535(93)90427-7

[58] Christensen, T.R., Panikov, N., Mastepanov, M., Joabsson, A., Stewart, A., Öquist, et al. (2003) Biotic Controls on $\mathrm{CO}_{2}$ and $\mathrm{CH}_{4}$ Exchange in Wetlands-A Closed Environment Study. Biogeochemistry, 64, 337-354.

https://doi.org/10.1023/A:1024913730848

[59] Schlesinger, W.H. and Bernhardt, E.S. (2013) Biogeochemistry: An Analysis of Global Change. Third Edition.

[60] Whalen, S.C. (2005) Natural Wetlands and the Atmosphere. Environmental Engineering Science, 22, 73-94. https://doi.org/10.1089/ees.2005.22.73

[61] Lai, D.Y.F. (2009) Methane Dynamics in Northern Peatlands: A Review. Pedosphere, 19, 409-421. https://doi.org/10.1016/S1002-0160(09)00003-4

[62] Shurpali, N.J., Verma, S.B., Clement, R.J. and Billesbach, D.P. (1993) Seasonal Distribution of Methane Flux in a Minnesota Peatland Measured by Eddy Correlation. Journal of Geophysical Research, 98, 20649-20655.

https://doi.org/10.1029/93JD02181

[63] Le Mer, J. and Roger, P. (2010) Production, Oxidation, Emission and Consumption of Methane by Soils: A Review. European Journal of Soil Biology, 37, 25-50. https://doi.org/10.1016/S1164-5563(01)01067-6

[64] Walter, B.P. and Heimann, M. (2000) A Process-Based, Climate-Sensitive Model to Derive Methane Emissions from Natural Wetlands: Application to Five Wetland Sites, Sensitivity to Model Parameters, and Climate. Global Biogeochemical Cycles, 14, 745-765. https://doi.org/10.1029/1999GB001204

[65] Abdalla, M., Hastings, A., Truu, J., Espenberg, M., Mander, Ü. and Smith, P. (2016) Emissions of Methane from Northern Peatlands: A Review of Management Impacts and Implications for Future Management Options. Ecology Evolution, 6, 7080-7102. https://doi.org/10.1002/ece3.2469

[66] Shindell, D.T., Faluvegi, G., Koch, D.M., Schmidt, G.A., et al. (2012) Improved Attribution of Climate Forcing to Emissions. Yale Journal of Biology and Medicine, 85, 167-185.

[67] McNamara, N.P., Plant, T., Oakley, S., Ward, S., Wood, C. and Ostle, N. (2008) Gully Hotspot Contribution to Landscape Methane $\left(\mathrm{CH}_{4}\right)$ and Carbon Dioxide $\left(\mathrm{CO}_{2}\right)$ Fluxes in a Northern Peatland. Science of the Total Environment, 404, 354-360. https://doi.org/10.1016/j.scitotenv.2008.03.015 
[68] Hanson, P.J., Gill, A.L., Xu, X., Phillips, J.R., Weston, D.J., Kolka, et al. (2016) Intermediate-Scale Community-Level Flux of $\mathrm{CO}_{2}$ and $\mathrm{CH}_{4}$ in a Minnesota Peatland: Putting the SPRUCE Project in a Global Context. Biogeochemistry, 129, 255-272. https://doi.org/10.1007/s10533-016-0230-8

[69] Dinsmore, K.J., Skiba, U.M., Billett, M.F., Rees, R.M. and Drewer, J. (2009) Spatial and Temporal Variability in $\mathrm{CH}_{4}$ and $\mathrm{N}_{2} \mathrm{O}$ Fluxes from a Scottish Ombrotrophic Peatland: Implications for Modelling and Up-Scaling. Soil Biology and Biochemistry, 41, 1315-1323. https://doi.org/10.1016/j.soilbio.2009.03.022

[70] Clymo, R.S. (1995) Methane and Carbon Dioxide Production in, Transport through, and Efflux from a Peatland. Philosophical Transactions of the Royal Society $A$, 351, 249-259. https://doi.org/10.1098/rsta.1995.0032

[71] Laine, A., Wilson, D., Kiely, G. and Byrne, K.A. (2007) Methane Flux Dynamics in an Irish Lowland Blanket Bog. Plant and Soil, 299, 181-193. https://doi.org/10.1007/s11104-007-9374-6

[72] Koehler, A.K., Sottocornola, M. and Kiely, G. (2011) How Strong Is the Current Carbon Sequestration of an Atlantic Blanket Bog? Global Change Biology, 17, 309-319. https://doi.org/10.1111/j.1365-2486.2010.02180.x

[73] Ballantyne, D.M., Hribljan, J.A., Pypker, T.G. and Chimner, R.A. (2014) Long-Term Water Table Manipulations Alter Peatland Gaseous Carbon Fluxes in Northern Michigan. Wetlands Ecology and Management, 22, 35-47. https://doi.org/10.1007/s11273-013-9320-8

[74] Moore, T.R., De Young, A., Bubier, J.L., Humphreys, E.R., Lafleur, P.M. and Roulet, N.T. (2011) A Multi-Year Record of Methane Flux at the Mer Bleue Bog, Southern Canada. Ecosystems, 14, 646-657. https://doi.org/10.1007/s10021-011-9435-9

[75] Lai, D.Y.F., Moore, T.R. and Roulet, N.T. (2014) Spatial and Temporal Variations of Methane Flux Measured by Autochambers in a Temperate Ombrotrophic Peatland. Journal of Geophysical Research: Biogeosciences, 119, 864-880. https://doi.org/10.1002/2013JG002410

[76] Blodau, C., Roulet, N.T., Heitmann, T., Stewart, H., Beer, J., Lafleur, P. and Moore, T.R. (2007) Belowground Carbon Turnover in a Temperate Ombrotrophic Bog. Global Biogeochemical Cycles, 21, GB1021. https://doi.org/10.1029/2005GB002659

[77] Moore, T.R. and Knowles, R. (1990) Methane Emissions from Fen, Bog and Swamp Peatlands in Quebec. Biogeochemistry, 11, 45-61. https://doi.org/10.1007/BF00000851

[78] Parasuraman, K., Elshorbagy, A. and Carey, S.K. (2007) Modelling the Dynamics of the Evapotranspiration Process Using Genetic Programming. Hydrological Sciences Journal, 52, 563-578. https://doi.org/10.1623/hysj.52.3.563

[79] Drexler, J.Z., Anderson, F.E. and Snyder, R.L. (2008) Evapotranspiration Rates and Crop Coefficients for a Restored Marsh in the Sacramento-San Joaquin Delta, California, USA. Hydrological Processes, 22, 725-735. https://doi.org/10.1002/hyp.6650

[80] Sun, L. and Song, C. (2008) Evapotranspiration from a Freshwater Marsh in the Sanjiang Plain, Northeast China. Journal of Hydrology, 352, 202-210. https://doi.org/10.1016/j.jhydrol.2008.01.010

[81] Wu, C.L. and Shukla, S. (2014) Eddy Covariance-Based Evapotranspiration for a Subtropical Wetland. Hydrological Processes, 28, 5879-5896.

https://doi.org/10.1002/hyp.10075

[82] Hollinger, D.Y., Kelliher, F.M., Byers, J.N., Hunt, J.E., McSeveny, T.M. and Weir, P.L. (1994) Carbon Dioxide Exchange between an Undisturbed Old-Growth Temperate Forest and the Atmosphere. Ecology, 75, 134-150. 
https://doi.org/10.2307/1939390

[83] Goulden, M.L., Daube, B.C., Fan, S., Sutton, D.J., Bazzaz, A., Munger, J.W. and Wofsy, S.C. (1997) Physiological Responses of a Black Spruce Forest to Weather. Agricultural and Forest Meteorology, 102, 987-996. https://doi.org/10.1029/97JD01111

[84] Souch, C., Grimmond, C.S.B. and Wolfe, C.P. (1998) Evapotranspiration Rates from Wetlands with Different Disturbance Histories: Indiana Dunes National Lakeshore. Wetlands, 18, 216-229. https://doi.org/10.1007/BF03161657

[85] Acreman, M.C., Harding, R.J., Lloyd, C.R. and McNeil, D.D. (2003) Evaporation Characteristics of Wetlands: Experience from a Wet Grassland and a Reedbed Using Eddy Correlation Measurements. Hydrology and Earth System Sciences, 7, 11-21. https://doi.org/10.5194/hess-7-11-2003

[86] Stamp, I., Baird, A.J. and Heppell, C.M. (2013) The Importance of Ebullition as a Mechanism of Methane $\left(\mathrm{CH}_{4}\right)$ Loss to the Atmosphere in a Northern Peatland. Geophysical Research Letters, 40, 2087-2090. https://doi.org/10.1002/grl.50501

[87] Shimoyama, K. (2003) Seasonal and Interannual Variation in Water Vapor and Heat Fluxes in a West Siberian Continental Bog. Journal of Geophysical Research, 108, 1-13. https://doi.org/10.1029/2003JD003485

[88] Lafleur, P.M., Hember, R.A., Admiral, S.W. and Roulet, N.T. (2005) Annual and Seasonal Variability in Evapotranspiration and Water Table at a Shrub-Covered Bog in Southern Ontario, Canada. Hydrological Processes, 19, 3533-3550. https://doi.org/10.1002/hyp.5842

[89] Iwata, H., Harazono, Y., Ueyama, M., Sakabe, A., Nagano, H., Kosugi, et al. (2015) Methane Exchange in a Poorly-Drained Black Spruce Forest over Permafrost Observed Using the Eddy Covariance Technique. Agricultural and Forest Meteorology, 214-215, 157-168. https://doi.org/10.1016/j.agrformet.2015.08.252

[90] Yu, X., Song, C., Sun, L., Wang, X., Shi, F., Cui, Q. and Tan, W. (2017) Growing Season Methane Emissions from a Permafrost Peatland of Northeast China: Observations Using Open-Path Eddy Covariance Method. Atmospheric Environment, 153, 135-149. https://doi.org/10.1016/j.atmosenv.2017.01.026

[91] Li, T., Li, H., Zhang, Q., Ma, Z., Yu, L., Lu, Y., et al. (2019) Prediction of $\mathrm{CH}_{4}$ Emissions from Potential Natural Wetlands on the Tibetan Plateau during the 21 st Century. Science of the Total Environment, 657, 498-508.

https://doi.org/10.1016/j.scitotenv.2018.11.275

[92] Cao, S., Cao, G., Han, G., Wu, F. and Lan, Y. (2020) Comparison of Evapotranspiration between Two Alpine Type Wetland Ecosystems in Qinghai Lake Basin of Qinghai-Tibet Plateau. Ecohydrology \& Hydrobiology, 20, 215-229.

https://doi.org/10.1016/j.ecohyd.2020.01.001

[93] Groffman, P.M., Hardy, J.P., Nolan, S., Driscoll, C.T. and Fahey, T.J. (1998) Snow Depth, Soil Frost and Nutrient Loss in a Northern Hardwood Forest. Hydrological Processes, 13, 2275-2286.

[94] Voigt, C., Marushchak, M.E., Lamprecht, R.E., Jackowicz-Korczyński, M., Lindgren, A., Mastepanov, et al. (2017) Increased Nitrous Oxide Emissions from Arctic Peatlands after Permafrost Thaw. Proceedings of the National Academy of Sciences of the United States of America, 114, 6238-6243. https://doi.org/10.1073/pnas.1702902114

[95] Saunders, D.L. and Kalff, J. (2001) Denitrification Rates in the Sediments of Lake Memphremagog, Canada-USA. Water Research, 35, 1897-1904.

https://doi.org/10.1016/S0043-1354(00)00479-6 
[96] Carvalho, M.T. de M., Madari, B.E., Bastiaans, L., van Oort, P.A.J., Leal, W.G. de O., de Souza, D.M., et al. (2016) Nitrogen Availability, Water-Filled Pore Space, and $\mathrm{N}_{2} \mathrm{O}-\mathrm{N}$ Fluxes after Biochar Application and Nitrogen Fertilization. Pesquisa Agropecuária Brasileira, 51, 1203-1212. https://doi.org/10.1590/s0100-204x2016000900020

[97] Fuchs, V.J., Mihelcic, J.R. and Gierke, J.S. (2011) Life Cycle Assessment of Vertical and Horizontal Flow Constructed Wetlands for Wastewater Treatment Considering Nitrogen and Carbon Greenhouse Gas Emissions. Water Research, 45, 2073-2081. https://doi.org/10.1016/j.watres.2010.12.021

[98] Martikainen, P.J., Nykänen, H., Crill, P. and Silvola, J. (1993) Effect of a Lowered Water Table on Nitrous Oxide Fluxes from Northern Peatlands. Nature, 366, 51-53. https://doi.org/10.1038/366051a0

[99] Arai, H., Hadi, A., Darung, U., Limin, S.H., Takahashi, H., Hatano, R. and Inubushi, K. (2014) Land Use Change Affects Microbial Biomass and Fluxes of Carbon Dioxide and Nitrous Oxide in Tropical Peatlands. Soil Science and Plant Nutrition, 60, 423-434. https://doi.org/10.1080/00380768.2014.903576

[100] Khirul, M.A., Kim, B.G., Cho, D., Yoo, G. and Kwon, S.H. (2020) Effect of Oyster Shell Powder on Nitrogen Releases from Contaminated Marine Sediment. Environmental Engineering Research, 25, 230-237. https://doi.org/10.4491/eer.2018.395

[101] Marushchak, M.E., Pitkämäki, A., Koponen, H., Biasi, C., Seppälä, M. and Martikainen, P.J. (2011) Hot Spots for Nitrous Oxide Emissions Found in Different Types of Permafrost Peatlands. Global Change Biology, 17, 2601-2614. https://doi.org/10.1111/j.1365-2486.2011.02442.x

[102] Hadi, A., Inubushi, K., Purnomo, E., Razie, F., Yamakawa, K. and Tsuruta, H. (2000) Effect of Land-Use Changes on Nitrous Oxide $\left(\mathrm{N}_{2} \mathrm{O}\right)$ Emission from Tropical Peatlands. Chemosphere-Global Change Science, 2, 347-358. https://doi.org/10.1016/S1465-9972(00)00030-1

[103] Huttunen, J.T., Nykänen, H., Martikainen, P.J. and Nieminen, M. (2003) Fluxes of Nitrous Oxide and Methane from Drained Peatlands Following Forest Clear-Felling in Southern Finland. Plant and Soil, 255, 457-462. https://doi.org/10.1023/A:1026035427891

[104] Nykänen, H., Vasander, H., Huttunen, J.T. and Martikainen, P.J. (2002) Effect of Experimental Nitrogen Load on Methane and Nitrous Oxide Fluxes on Ombrotrophic Boreal Peatland. Plant and Soil, 242, 147-155.

https://doi.org/10.1023/A:1019658428402 